\title{
Coping Mechanisms to Mitigate Occupational Stress by Women in Accra Metropolis
}

\author{
Charity Odumale Roberts ${ }^{1}$, Kwasi Sarfo' ${ }^{1}$, Isaac Nyarko Kwakye ${ }^{2}$ \\ ${ }^{1}$ Department of Languages and General Studies, University of Energy and Natural Resources, Sunyani, Ghana \\ ${ }^{2}$ Department of Psychology, West End University College, Accra, Ghana \\ Email: ^charity.roberts@uenr.edu.gh, kwasi.sarfo@uenr.edu.gh, mannixike@gmail.com
}

How to cite this paper: Roberts, C. O., Sarfo, K., \& Kwakye, I. N. (2021). Coping Mechanisms to Mitigate Occupational Stress by Women in Accra Metropolis. Open Journal of Social Sciences, 9, 207-227. https://doi.org/10.4236/jss.2021.96017

Received: April 30, 2021

Accepted: June 20, 2021

Published: June 23, 2021

Copyright $\odot 2021$ by author(s) and Scientific Research Publishing Inc. This work is licensed under the Creative Commons Attribution International License (CC BY 4.0).

http://creativecommons.org/licenses/by/4.0/ (c) (i) Open Access

\begin{abstract}
Everyone experiences stress in different life situations. In particular, occupational stress affects the performance of employees positively or negatively depending on their perception and the personality traits. This paper addresses how women in managerial positions in the Accra Metropolis manage the occupational stresses they experience in the discharge of their duties. The convenient purposive sampling technique was used to select 10 females from 150 women in managerial positions in government institutions in the Accra Metropolis. A structured interview guide based on Occupational Stress Inventory-Revised OSI-R was used to collect data from the 10 women and analysed using factor analysis. The study revealed that respondents managed their stresses by employing recreation, social support, and self-care. Even though, some of the women unknowingly adopted rationalization or rational-cognitive defence mechanisms to cope with the stresses they experience, none of them used popular stress reducing techniques such as yoga and physical exercise to cope with their stresses. The resilience of these women coupled with the formulation and implementation of formidable policies, provision of conducive working environment and the requisite resources by employers will go a long way to alleviate the women's stresses while promoting their good health and productivity. This research paper addresses the strategies adopted by Ghanaian women in managerial position to manage their stresses and proposes that individual differences and religiosity of persons should be taken into consideration when counselling people on stress management.
\end{abstract}

\section{Keywords}

Stress, Occupation, Relational-Coping, Recreation, Coping, Music

\section{Introduction}

Stress is a major cause of concern for everyone because of its effects, especially in 
this era of technology and development. The world of work is saddled with stress. Men and women have equal opportunities to be employed in all sectors of the economy. An individual's ability to gain appointment to any employment therefore depends on the acquisition of the requisite skills and qualification required for the achievement of the institutional goals without any consideration to gender, ethnic group or age (OECD, 2012).

Women in formal employment who have risen through the hierarchical ranks to occupy managerial positions have oversight responsibility of the institution. They also support staff members for optimum productivity while they continue to perform their primary duties of housework and child care (Amu, 2005). Women are culturally marginalized in decision-making processes both at the household and community levels leading to non-consideration of their interests and aspirations (Stamarski \& Son Hing, 2015; Diabah \& Amfo, 2015). Several studies (Glazebrook, Noll, \& Opoku, 2020; Thurston, Sherwood, Matthew, \& Blumenthal, 2011) have shown that women invest more time into family and household chores than men even when they secure salaried employment and this increases their overall workload and places restrictions on them. They, unlike men therefore lack the time to commute long distances to do overtime or weekend work and this affects their wage-earning potentials (Diabah, 2018; Yearbook, 2013).

Even though women continue to dominate domestic work by spending three times more hours in a week than their male counterparts, they spend practically the same amount of time as men on productive work (Amporfu, Sakyi, Frimpong, Arthur, \& Novignon, 2018). The combination of various roles of women, especially those associated with their roles as mother, partner, and employee generate harmful stresses on their wellbeing (Hegewisch \& DuMonthier, 2016). As more females especially mothers enter into the workforce, their stress upsurges due to increases in working hours, job instability and new technologies. This may be the result of the women's inability to clearly discriminate between their roles in the home and the work place owing to their desire to attain the expected results in both places (Adekola, 2010; Nkulenu, 2015). Women even though multi-tasked and resourceful, have been domesticated to accept their traditional roles which have been reinforced by patriarchy and colonialization to accept the gender stereotype of being poor performers and subordinates when they are compared with men (Ganle, Afriyie, \& Segbefia, 2015; Sackey \& Sanda, 2011).

The conditions of the work environment such as pollution, poor ventilation, insecurity and overcrowding; coupled with work demands like role overload, role ambiguity, role conflict, lack of resources and control; and life conditions comprising lack of social support and single parenting are some of the factors that have worsen the stress of women in management positions (WHO, 2018). This is the web that has engulfed working women especially those in managerial positions in government institutions in the Accra Metropolitan Area. The negative effects of multiple roles of these women call for strategies to help them re- 
duce their stresses while maintaining their mental health and increased productivity. The burden of double employment: gender roles at home and work place has devastating effect not only on the physical, emotional and mental well-being of the women but also on their productivity in the work place (Sackey \& Sanda, 2009; Roberts, 2014).

A considerable number of researches have been conducted in many countries including Ghana on the variables related to occupational stress. Researchers (Kusi et al., 2018; Addison \& Yankyera, 2015; Sackey \& Sanda, 2011; Ofei et al., 2018; Amponsah et al., 2020) have focused on other dimensions of the phenomenon. For example, Benson et al. (2020) focused on the challenges, coping strategies, and social support among breast cancer patients in Ghana; the study of Adansi et al. (2020) explored the gender differences in the stressors experienced by teacher education students at the University of Ghana while Addison and Yankyera (2015) conducted an investigation into how female teachers manage stress and teacher burnout. Others such as Sackey and Sanda (2011) dealt with sustenance of human capital: social support as a managerial stress reliever for women in developing economies. A critical look at the discussions indicates that there is a paucity of research on the coping strategies of female managers in government institutions in the Accra metropolis. It is against this background that the current study explores the coping strategies that women in managerial positions in government institutions adopt in a bid to maintain good health, achieve results and impact their society positively. This study therefore examines the coping strategies employed by women in managerial positions in government institutions in Accra metropolis to mitigate the impact of the burden of occupational stresses they experience in the course of their work.

\section{Literature Review}

Stress can be defined as the "response of the body to any demand, whether it is caused by, or results in, pleasant or unpleasant conditions" (Selye, 1976: p. 74). Persistent exposure to occupational stress can have detrimental effects on the health of the employee, their productivity and the financial gains of the institution. Occupational stress also contributes to decrease organizational performance, high error rate and poor quality of work, high staff turnover, and absenteeism due to health problems such as emotional disorder, anxiety, work-life imbalance, depression, headache, obesity and cardiac arrests (Ajayi, 2018; Okeke et al., 2016).

Stress can have both positive (eustress) and negative (distress) effects, but the absence of stress in one's life is death (Trivellasa et al., 2013; Nadinloyia et al., 2013). Eustress increases people's alertness and energy to meet challenging situations whilst distress prevents people from achieving set goals (Robbins \& Sanghi, 2006). Different people experience the effect of stress differently as result of their perception and personality. Perception can either be objective or subjective depending on how the situation is interpreted; and can therefore be affected by 
fear, which may be rational or irrational (Willis, 2005). Certain personality traits have been found to mediate the stressor and strain (Jones \& Bright, 2001). Individuals with high internal loci of control exert greater control of their environment and health and are therefore more resistant to stress than externals (individuals with low control) who report higher levels of stress and strain (Rotter, 1966; Semmer et al., 1996).

Lazarus and Folkman (1984), define coping as "constantly changing cognitive and behavioral efforts to manage specific external and/or internal demands that are appraised as taxing or exceeding the resources of the person". They cautioned that coping should not be equated to mastery over the environment, as many sources of stress cannot be mastered; and further described effective coping as "that which allows the person to tolerate, minimize, accept or ignore what cannot be mastered". Halbesleben (2010) uses the concepts "fight" and "flight" to distinguish between active and avoidant coping and indicated that if we have the resources to fight, we do but if we don't have those resources, we run.

Coping involves the ability to engage in problem solving, accept what we cannot change and make adjustments in ourselves to master, minimize or withstand the stresses in our daily lives (Baltus, 1997). Coping mechanisms can be grouped into three: appraisal-focused strategy which comprises changing the way we think about a problem by altering the goals and values. The problem-focused strategy deals with the cause of the problem or stressor by eliminating the source of the stress but those using the emotion-focused coping strategies address the feelings associated with the stressor by modifying the emotions that accompany stress perception by releasing, distracting, or managing their mental state. No single approach of coping meets the needs of every stressed individual. Personal choice in coping strategies is therefore key; and determined by personality traits and type, social context, and the nature of the stressor involved (Willis, 2005).

Individual and organisational approaches like physical exercise, stress awareness training, seminars or health circles, strengthening of social support and work redesign have all proven to buffer the harmful effects of stress and strain (Pines \& Aronson, 1988; Innstrand, Espnes, \& Mykletun, 2004). However, one does not have to reduce all the stressors or mismatches but rather choose a mismatch of major concern whose resolve has the potential to generate and allow the execution of concrete solutions. No matter the type of intervention or approach used, the worker's involvement in the process as well as the support from top management are critical to its success (Kompier \& Cooper, 1999).

The theoretical framework underpinning the study was adapted from Osipow and Davis (1988) and Lazarus and Folkeman (1984). They claimed that coping strategies mediate the relationship between stressors and strain, thus occupational stressors, strain and coping resources interact. Osipow and Davis (1988) postulated that stressors originating in the work environment influence how individuals perceive their work roles; which means when work stressors interact with stress-inducing work roles, personal or psychological strain results; and fi- 
nally that the variety, strength and level of coping resources an individual possesses influences both the presence and level of strain. Stress is a highly personalized phenomenon and can vary widely even in identical situations for different reasons. For instance, if two individuals with the same occupational stressor, the difference in coping resources would serve to mediate the resulting strain. High occupational stressors for example do not necessarily predict strain but it can be predicted depending on the extent to which coping resources exist (Osipow, 1998). The individual can use social support, recreation, physical exercise and rational-cognitive coping strategies as some of the coping resources.

Figure 1 is a diagrammatic representation of the present study's conceptual framework. The model suggests that occupational stressors such role-overload, role insufficiency, role ambiguity, role-conflict and physical environment pose threats to individuals in the work place. Role-overload for example assesses the extent to which role demands are perceived by the individual as exceeding his or her personal and workplace resources and perceived ability to accomplish expected workload. Role insufficiency on the other hand is the extent to which an individual's trainings, education, skills and experience are appropriate for the work he/she performs; while role ambiguity measures the degree to which priorities, expectations and evaluation criteria are clear to the individual. Role boundary considers the extent to which conflicting role demands and loyalties are experienced in the work context but role responsibility assesses the degree to which the amount of responsibility the individual has or feels for the performance and welfare of other people at work. Individuals with high scores in responsibility are frequently needed for leadership and guidance. Furthermore, physical environment considers the amount of exposure to extreme physical conditions or environmental toxins that may pose a threat to the individual in the work environment. The theoretical model suggests that the degree of threat or the resulting stress posed by the occupational stressors depends on the individual's coping mechanisms.

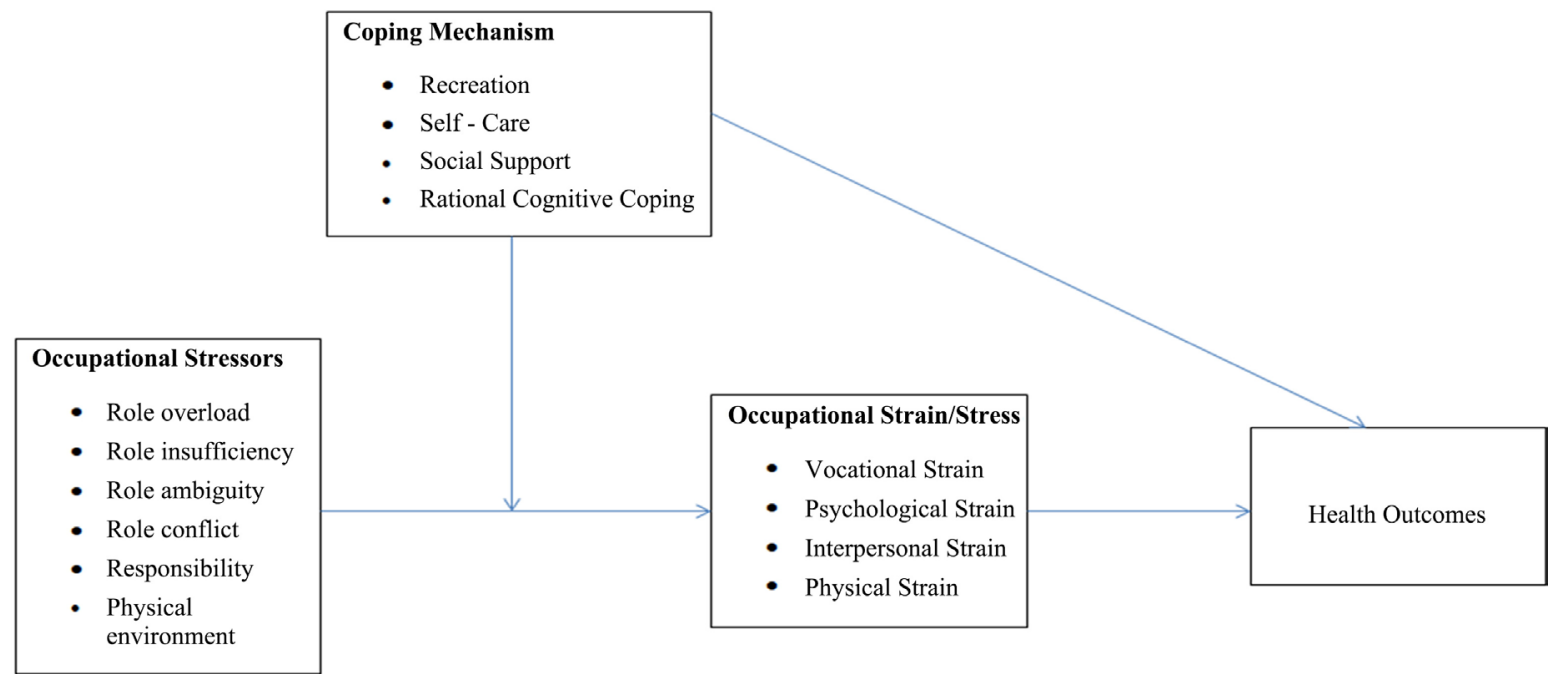

Figure 1. Conceptual framework of the theoretical model for the study. 
Coping mechanisms therefore are the techniques or strategies that an individual adopts in an attempt to cope with stressors, maintain self-esteem and adjust to unpleasant realities in life. These coping mechanisms may take the form of recreation, self-care, social support and rational-cognitive coping. Rational-cognitive coping is a psychological strategy that people adopt in stressful situation. For example, an employee who is experiencing role overload may cope with this stressor by rationalising that "well, I am lucky that I have a job and so I should not complain that I am doing too much". Such rationalization may serve to mediate the stressor and the stress that could manifest itself in the individual such as taking too much time off-work or becoming irritable with work colleagues.

The conceptual model also shows that the stress or occupational strain can manifest itself in different ways including vocational strain which is the degree to which an individual has difficulty producing work quality or output and manifested in the area of work productivity, attendance and job satisfaction. Psychological strain which relates to the individual's reported ability to adjust psychologically and emotionally. It is seen in affective subjective responses of various types, including: anxiety, depression and tiredness; Interpersonal or behavioural strain which is the disruption in interpersonal relationships which the individual experiences and is manifested in behaviours like withdrawal, isolation, anger and irritability towards others. Physical strain covers the domain of physical illness or poor self-care habits, which the individual may exhibit including psychological-based disorders, cardiovascular and other health implications. Other manifestations of strain may include sleep and eating disorders, as well as substance abuse.

In summary, the theoretical model as shown in Figure 1 suggests that when an individual employee is going through a situation in the workplace which he or she sees as threats (stressors), such as heavy work load and conflicting task from supervisors, the effects of these which can be absenteeism, depression, withdrawal from people, sleeping and eating disorders (strain) can be reduced if the person adopts some coping techniques, like exercise, and talk to someone when experiencing the threats (stressor). Thus, the coping mechanisms will interact with the stressors and reduce their effects. In other words, it will moderate or mediate between the stressors and the strain.

\section{Methodology}

\subsection{Research Design}

The qualitative research paradigm was adopted for the study. It uses diverse contrasting methods to study the meaning of people's lives in real life situations, collect first-hand information on the experiences or perception of the actors or respondents and represent their views and perspectives in contextual conditions while contributing insights into existing and emerging concepts to help explain human social behavior using multiple sources of evidence (Yin, 2011). The study 
focused on the management of occupational stress by women in managerial position in government institutions in the Accra Metropolis. To investigate this phenomenon, the study considered the perceptions, views and behaviors of the participants in order to obtain detailed information as suggested by Picciano (2004). The qualitative design helps researchers to understand the "what", "how" and "why" of a particular action (Saunders, Lewis, \& Thornhill, 2009). A variance of the case study design was used to collect in-depth information from the unit of analysis who were the women in this study. The case study design was adopted because it generated rich, contextually detailed, and valid process data that left the participants' perspectives minimally altered; and enabled in-depth exploration of the topic (a program, a process, an event, an activity) or one or more individuals (McCombes, 2019; Creswell, 2009).

\subsection{Sample and Sampling Technique}

The target population for the present study was all the fifty females in managerial positions in government institutions in the Accra Metropolis. These women in the institutions were selected because their resources and characteristics are in line with the subject for discussion. To Punch (2005), the population is the total target group who would, in ideal world, be the subject of the research, and about whom one is trying to say something about.

The purposive sampling techniques were adopted for the study. Accra Metropolis was purposively selected for the study because many government institutions are situated there. The purposive sampling technique was adopted because the researcher selects members of the population to participate in the study in a deliberate manner to yield the most relevant and plentiful data considering the topic of study. It also ensures that the respondents are easy to recruit and would be available throughout the period and it is cost effective (Yin, 2011). The study used homogenous sampling which focuses on a particular sub-group where all the sample members were similar as in an organisational hierarchy (Saunders et al., 2012). The purposive sampling method was used to select 10 women based on their rank in their institutions, their availability, willingness to participate in the study as well as their ability to provide in-depth information on their experiences. The researchers visited the study area to purposively contact and collect in-depth information from respondents who occupy the requisite position for the study in various institutions. The researchers introduced themselves, explained the purpose of the research and assured them of confidentiality. Participation was voluntary and based on informed consent. Individuals who were willing to participate in the study were interviewed to collect first-hand information on their experiences.

\subsection{Data Collection Instrument and Data Collection}

The interview guide was developed using Osipow \& Spokane's (1984) Occupational Stress Inventory-Revised Edition (OSI-R). According to Osipow (1998), the Occupational Stress Inventory-Revised (OSI-R) is a psychometrically vali- 
dated stress questionnaire built on a broad theoretical base with normative data which enables comparisons with other professional groups. The OSI-R assesses three interrelated overall dimensions, each being important in the experience of occupational adjustment-occupational role stress, psychological strain and coping resources. The items on the OSI-R questionnaire were compressed to three main headings (titles) which were the determinants of stress, the symptoms of stress and the strategies for coping.

The semi-structured interview guide was adopted because of its flexibility in allowing respondents to speak about their experiences and explore issues into more detail. The interview guide consists of two main sections: the demographic data and coping strategies. There was a chain of open-ended questions on stress management strategies comprising four subheadings: recreation, self-care, social support and rational cognitive coping. The questions under "recreation" seek to find out activities that provided distraction or entertainment from stressful events and a source of satisfaction outside the work environment for the women. The second group of questions under the subheading "self-care" identifies the female managers' involvement in healthy activities such as regular check-up and exercise; dieting habit (sugar, drugs, alcohol, tobacco and coffee) and relaxation techniques. Questions under "social support" were to determine the relationships respondents had with family and friends as well as social groups. These relationships served as a source of coping resource to insulate them from the effects of their stresses. The last group of questions under the subheading "rational-cognitive coping" sought to determine the interviewees' ability to reduce stress through the effective management of time and effort.

Follow-up questions were developed to ensure that all the respondents considered the same topic and to clarify points raised. Permission was sought and the purpose of the study was also explained to the respondents before the data collection. They were assured of confidentiality and all ethical considerations were observed. The face-to-face interview which was conducted in English lasted between 20 to 30 minutes, was audio recorded, transcribed and factor analysed. Notes were taken during the interview sessions on observable occurrences which the audio-recordings might omit. To protect the identity of the respondents, pseudo names were given them and other information were securely kept.

\subsection{Data Analysis}

The data collected was analysed using factor analysis to reduce the number of variables by finding the common factors without losing the information the original variables provided (Punch, 2005). Factor analysis also enabled the researchers to reduce and structure all the recorded data collected without losing the relevant information. Direct quotations from the respondents were used to depict the results of the study.

\subsection{Summary of the Basic Characteristics of Respondents}

All the participants were females whose ages ranged from 35 to 57 years; with an 
average age of 50 years. Seven $(n=7)$ of them were married, two (2) were single and one (1) widowed. They all had dependants with the least being two. While seven (7) of them have four (4) dependants each, two (2) others have seven (7) dependants and ten (10) respectively. The researcher did not probe further to determine whether they were their biological children or guardian. They had diverse educational qualifications: State Registered Nurse (SRN)/Midwife $(n=2)$; Bachelor's degrees $(n=3)$ and Masters' degrees $(n=5)$. Their working experience ranged from 5 years to 35 years (Table 1 ).

\section{Findings and Discussion}

Occupational stress is a general problem that has health and cost implications to the individual, organisation and country as a whole. This study explores the coping strategies adopted by these women to cope with the stresses they experienced in pursuance of their domestic and organisational jobs.

From the study, almost all the women $(\mathrm{N}=9)$ in managerial position were elderly women whose age ranges between 45 - 58 years and had work experiences spanning between 20 - 35 years. Their average age for entering the workplace was 24 years 9 months while their average work experience was about 27 years. It is therefore important to note that these women might have gathered rich experiences from long service over the years, accompanied by the requisite qualification which cushion them in their current positions to manage their "office" and their stresses effectively. It is worth noting that Amanda, even though the youngest among the respondents entered the workplace at an older age than the average age but occupies managerial position with only five (5) years working

Table 1. Summary of the basic characteristics of respondents.

\begin{tabular}{|c|c|c|c|c|c|c|c|}
\hline $\mathrm{S} / \mathrm{N}$ & $\begin{array}{l}\text { Pseudo } \\
\text { Names }\end{array}$ & Age & $\begin{array}{c}\text { Marital } \\
\text { Status }\end{array}$ & $\begin{array}{c}\text { No. Of } \\
\text { Dependents }\end{array}$ & $\begin{array}{c}\text { Academic } \\
\text { Qualification }\end{array}$ & $\begin{array}{c}\text { Work } \\
\text { Experience } \\
\text { in Years }\end{array}$ & Rank \\
\hline 1. & Amanda & 35 & Married & 2 & $\begin{array}{l}\text { BA Social } \\
\text { Science) }\end{array}$ & 5 & Assistant Director 2B \\
\hline 2. & Tina & 55 & Widow & 4 & SRN/Midwife & 31 & $\begin{array}{c}\text { Principal } \\
\text { Nursing Officer }\end{array}$ \\
\hline 3. & Belinda & 47 & Married & 4 & B.A/B. L & 20 & Director \\
\hline 4. & Monica & 45 & Married & 4 & M.Phil. & 25 & Assistant Director 1 \\
\hline 5. & Connie & 48 & Married & 4 & M.A & 31 & $\begin{array}{c}\text { Principal } \\
\text { Superintendent }\end{array}$ \\
\hline 6. & Gina & 49 & Married & 4 & MBA & 24 & $\begin{array}{c}\text { Director, Human } \\
\text { Resource }\end{array}$ \\
\hline 7. & Paulina & 53 & Married & 4 & M.A & 21 & General Manager \\
\hline 8. & Helena & 58 & Single & 10 & SRN & 35 & $\begin{array}{c}\text { PNO/Acting } \\
\text { Deputy Director }\end{array}$ \\
\hline 9. & Irene & 56 & Single & 4 & BA/LLB & 30 & Manger \\
\hline 10. & Winnie & 57 & Married & 7 & M. A & 32 & Director \\
\hline
\end{tabular}


experience which is still older than the average age the other respondents commenced work. Even though some studies have shown that women delay in rising to managerial position, the current study finds Amanda occupying that position at age 35 years with only five years working experience. This could not be the situation of the other women even though the study did not seek the age at which they had their promotions to the managerial positions. These positions or ranks are often permanent positions and therefore individuals who got to that position can either rise to other higher positions within the managerial rank or remain on that rank until they retire.

From observation and through our interaction with the women, we realised that Amanda, the youngest respondent was more stressed than the others; and this could probably be due to the overwhelming effects of her dual roles in the home and workplace accompanied by her inability to select appropriate coping tools to mitigate the stressors she encounters in the course of her dual responsibilities. The older respondents who we perceive, had gone through stressful situations over the years have accrued rich experience and had developed their resilience. They have therefore found more rewarding ways of dealing with their stresses using coping resources such as rational-cognitive coping, recreation and self-care.

Majority of the women in the study were married with the exception of only three who were either single, divorced or widow. These women also extensively depended on their husbands as their social support in the management of the stresses they experienced in the course of their work even though many may think that with their level of empowerment and position they would derive inner strength (internal locus of control) or other reliable strategies for stress management other than their husbands. Studies by Folke, Olle, and Johanna Rickne (2020) have shown that many women who are highly educated and most often occupy managerial positions are either divorced or single but this discords to the findings of the present study where majority of the women were married.

\subsection{Recreation}

Based on factor analysis, the coping strategies adopted to mitigate their stresses were categorised broadly under four major thematic areas: recreation, self-care, social support and relational cognitive coping. These are consistent with previous studies (Kusi et al., 2018; Wireko-Gyebi et al., 2017; Roberts, 2014; Addison \& Yankyera, 2015). For recreation, the women in the current study stated that they "take day off" whenever they do not feel well, have something else to do or when they feel tired. They either inform their bosses or absenting themselves from work. Some of their explanations are:

Irene: "Yes, I tell my boss I want to rest when I feel I am tired."

Amanda: "I take a day off when I am not well."

Belinda: "Yes, if I have something else, I have to do, I take a day off work to attend to it." 
They mentioned listening to music, dancing, sleeping, chatting, watching TV and films, gardening, attending social activities as well as church services and meditating on the word of God as some recreational activities they enjoy during leisure time. For example

Irene: "I love reading spiritual materials, watching Christian TV channels, dancing, chatting and organising people (parties)."

Belinda: "I just watch T.V., converse, visit friends and talk."

Helena: "I like church activities, counselling people and helping people. I like listening to preaching, gospel songs and reading. I like doing gardening, if I am not on duty that is what I have been doing. I do it until I am tired and I leave the place."

Winnie: "sometimes I can just take an album or pictures, I look at a lot of pictures, cast my mind to the good days. By the time I finish going through the album I am relaxed. I also listen to music or watch a good programme on T.V. for the mind to relax."

Like the respondents in the study, majority of the female teachers and the female Lectures in the study conducted by Addison and Yankyera (2015) and Kusi et al. (2018) respectively took days off by applying for casual leave or compulsory leave as an opportunity to move away from the stressful (work) environment that causes them stress and get refreshed so that they could carry out their roles and responsibilities more meaningfully. Only a few of the frontline workers in the study by Wireko-Gyebi et al., however "take time off work" and this could possibility be their doubt of their employers granting their request for a "day off" or because they feared losing their jobs or suffering a reduction in their salaries as a result of absenteeism. The negative response from majority of the women in the study that they do not "set time to do the things they really enjoy" contradicts that of previous study by Addison and Yankyera (2015) where majority of them responded positively that they "set time for enjoyment" and the female Lecturers (Kusi et al., 2018) who take compulsory leave to travel to key tourist centres for relaxation. The women in managerial positions in the current study however explained that they were unable to set specific "set time to do the things they really enjoy" either because of their irregular work demand or their inability to adhere to particular set time when the going becomes tough. For example:

Helena: "If I have something to do, I do not waste the time even if I do not have anything doing I still do not set time because sometimes on my off duty days, I may be called upon to do something in the office."

Recreational activities play multiple roles in the lives of individuals including reducing stress, promoting relaxation, social support and wellbeing (Kerr et al., 2012; Roberts, 2014; Park \& Kim, 2018; Kusi et al., 2018; Coleman \& Iso-Ahola, 1993; Addison \& Yankyera, 2015). According to Maddi and Khoshaba (2005); Lemay, Hoolahan, \& Buchanan (2018) and Riley \& Park (2015) physical activities and meditation are effective resources for managing work-related stresses which can lead to effective work climate. The women in the current might not 
have used physical exercises consciously because of their individual differences like coping styles and personality dimensions which would determine their benefit or otherwise (Myers et al., 2012; Folkins \& Sime, 1981). They might have engaged in physical activities or exercise unconsciously. For example:

Winnie: "Sometimes I go for a walk within my vicinity. I do not have definite time for it because it has become a routine. It is part of me."

\subsection{Self-Care}

From the findings, "Self-Care" was another coping strategy the women in managerial positions employed to alleviate their stresses. They resort to having regular exercises, meditating on God's word, sleeping eight (8) hours a day, being careful about their diet, practiced relaxation while avoiding harmful substances and coffee to moderate their stresses. The women's choice of "self-care" was in consonance with previous studies (Myers et al., 2012; Clark, 2013; Addison \& Yankyera, 2015; Kusi et al., 2018). While the female teachers (Addison \& Yankyera, 2015) avoided unhealthy things because they were above 40 years and were getting weaker, the female Lectures (Kusi et al., 2018) resorted to healthy eating, however the women in the current study avoided foods and drinks they know were unhealthy for them. Typical examples of the things they avoid were as follows:

"Any wise person will do that unless you do not like your life. I do not take coke and the minerals, because when you take a bottle you have taken nine cubes of sugar and I also avoid the fatty (meat) foods. It's unfortunate that instead of living on vegetable, I am unable to do it because of the nature of the work. My eating habits too is not regular."-Tina

"I keep away from foods such as sweets and other sweet things unless they are necessary because of my health and weight; I try to avoid them."-Helena

"I do not take alcoholic beverages; maybe occasionally I take a little wine when there is a wedding reception somewhere. These days I am even cutting down on sugars. I am trying to even take the beverage without sugar. It is not easy if you are used to making your tea with sugar. I am also used to making my tea with lime instead of milk." -Winnie

The study by Addison and Yankyera (2015) revealed that the female teachers take in certain drugs to aid them relax and reduce their stress situations, which was contrary to the current study where the women asserted that they do not practice any kind of "relaxation"/|or yoga but they have developed other strategies to help them relax. Their responses include:

"I do not practice that kind of relaxation but I have my own way of going through. I can just lie down singing in my head resting, meditating on the word but not in that sense."-Winnie

"I close my eyes to think about other things or meditate, focus on God's word."-Pauline

"I sit to read, listen to music and watch television/films or sleep."-Tina 
The women in management positions did not have regular check-ups because they do not have time for it unless they were not fine however, the female teachers complained that they could not adopt "regular check-ups" at the hospital due to their work overload.

\subsection{Rational/Cognitive Coping}

The women in the present study also employed rational coping strategies to ease their stresses. They claimed they think through choices, go through options, ask a lot of questions from co-workers, sister or friends, weigh the pros and cons, consider the issue at stake and also rely on God to make their decisions "when faced with the need to make a decision". Their responses included the following:

Pauline: "I think through choices to come out with the right decision and consult where necessary."

Helena: "I ask a lot of questions from my co-workers or sister or friends. I do not like taking decisions alone. Normally when I want to take a decision, I invite those that I work with, we put our heads together and then take it."

Tina: "It's only God who helps us and the Holy Spirit is always with us. The Lord directs me in all my ways and decisions. I have Christian friends and the pastors who I also consult when the need arises."

This was congruent with previous studies (Ofei et al., 2018; Owusu \& Tawiah, 2014; Addison \& Yankyera, 2015). Ofei et al. (2018) and Owusu \& Tawiah (2014) found out that the senior staff female administrators, nursing managers and the female teachers respectively dealt with their work-related stresses by managing their time and prioritizing their schedules just as the women in the current study but the female Lecturers (Kusi et al., 2018) mentioned "effective time management" as an additional stress management. The women in the current study were able to put their jobs out of their minds when they go home because they believe there were other jobs besides the office one that they can do contrary to the views of the female teachers (Addison \& Yankyera, 2015) who were not in the habit of putting their job out of mind when they go home. Some of the responses they gave to support their answers were as follow:

"Yes, when I leave the office, I forget about every work."-Pauline

"Yes, when I leave the office, I do not think about the work there."-Belinda

"Yes, when I leave here the work is behind me; I just concentrate on what is at home after that I sleep soundly until the next day."-Winnie

"sometimes but not always because when I have to go for a meeting and I have something to do in the office I have to make sure I come early to complete it before the time of the meeting."-Belinda

"Yes, sometimes I plan but at other times things crop up and I have to attend to them."-Gina

"Yes, I have to do list or work schedule for the day so I prioritize what need to be done first."-Pauline

"Yes, I have plans that I follow and I do not allow anything to take precedence 
over that."-Amanda

"Yes, first things first; I do things that are pressing first. I set my priority first."-Helena

Forbus et al. (2010) also found out that commuting students unlike residential students adopted positive active strategies such as planning, time management and developing resolutions to overcome their stresses. The women in the current study indicated they were able to think through choices when they make a decision.

The women in the present study also used religious coping both as social support and rational-coping to manage the stresses they experienced. Below are some of their responses to illustrate the use of God both as social support and rational coping strategy:

Tina: "Yes, God. This is because I have been a widow for the past ten years and it is only God who cares and provides for me and my children"-(social support)

Tina: "It's only God who helps us and the Holy Spirit is always with us. The Lord directs all my ways and decisions. I have Christian friends and Pastors who I also consult when the need arises" (rational-coping).

Several researches (Oti-Boadi \& Asante, 2017; Donkor \& Sandell, 2009; Roudsari \& Allan, 2011) support religious coping, even though religion can have both positive and negative effects. Religion plays a fundamental role in the life of Ghanaians and Africans when dealing with stressful situations (Gyekye, 2003). Their religiosity and use of prayer and meditation is also consistent with findings by Amponsah et al. (2020) as seen in their summary response below:

"I love reading spiritual materials, listening to gospel music, watching Christian TV channels and meditating on the word of God."

"Yes, God, I do not rely on any human being."

Religious and Spiritual coping can effectively reduce the negative effects of stress of women but the symptoms of stress and depression in the women would yield high distress when wrong methods including getting angry at God for their problems is applied (Ryan, 1998; Pargament et al., 1998; Hall et al., 2012). Empirical studies have also shown that when women who are religious experience any stressful situation such as infertility, they take it as a spiritual crisis which threatens their core beliefs about life, self and ultimate truths (Oti-Boadi \& Asante, 2017; Ryan, 1998). The respondents in the present study are testament of African in the remark of Mbiti that "The African is notoriously religious" and religion forms part of their cultural values (Mbiti, 1969) and according to Twumasi (1975), the distinction between physical cure and magico-religious cure is not emphasized since the diagnosis and treatment of illness are deeply entrenched in the utilization of the supernatural. It is important to acknowledge the fact that religion and spirituality are indispensable tools in the management of stress for the Ghanaian especially women because religion is an aspect of the African cultural values. African religion stresses the need to pursue and attain human wellbeing in life by carefully balancing the need for spiritual and moral 
values (Abarry, 1997). These findings are also in consonance with the previous studies that women used spirituality as a coping resource (Hall et al.., 2012) and Bacchus (2008) establish that black women's spirituality was a coping tool they used to mediate the work-related stresses they experienced.

\subsection{Social Support}

All the women indicated that they had a "shoulder to cry" on as social support to manage their stress they experienced. They relied mostly on family members, friends and God. Their responses include:

"Yes, my children and sometimes my husband."-Connie

"Yes, my mother and my husband."-Amanda

"Yes, God, I do not rely on any human being."-Gina

Irene and Helena: "Yes, my best friend" and "sister" respectively.

Their choice of social support is consistent with the findings of Addison and Yankyera (2015). Whilst the respondents relied mostly on family members, friends and God, the female teachers in the study by (Addison \& Yankyera, 2015) sought professional assistance from their religious leaders, doctors, lawyers and counselors as their social support. Women look for more social support than men and therefore they easily make friends, speak their mind and most often fond of complement. They therefore implore support in the form of advice, information, practical assistance, counselling and emotional support (Greenglass, 2002; Clarke \& Cooper, 2000). Women also benefit from social support than men because the socialization of men discourage emotional expression and encourage goal-oriented independent effort (Gonzalez et al., 2006). Findings by Sackey and Sanda (2011) and LeDuc (2010) showed that majority of their respondents indicated that they had people who cared and are committed to their wellbeing.

\subsection{Implications}

The findings of the study have brought to bear a number of approaches to prevent the occurrence of occupational stress in the work place which has repercussion for employees and all stakeholders in the industry. The findings of the study are vital from the point of view of coping strategies and how they mitigate the stresses experienced by the women in managerial position. Often, it is rare to find many women in managerial positions and therefore it has become necessary for the biological and socio-cultural factors of gender to be considered to improve their wellbeing, relationship with society and increase productivity. Thus, it is essential to provide conducive environment both at home and the workplace together with the appropriate support systems to minimize their stress levels. The study has provided valuable data for future research which should be conducted with larger sample of diverse categories of working women for generalization of the findings. The level of stress and the stress management strategies adopted by the women should be objectively assessed in future studies to ascertain the severity or otherwise of their stress and the effectiveness of the strategies 
respectively. Women with younger children should be allowed to close earlier than the normal time and they should also be educated to be aware of the tendency to transfer their stresses from home to the work place and vice versa. The tendency of an employee to bring work related problems home and also take family problems to work depends on their educational background, the strength of their family support, and the amount of time available for them to relax. Giving job descriptions to workers will enable them to be aware of the hazards in their work and develop ways to cope with it. Even though, a certain amount of stress can be good for the organisation and individual, too much stress can have devastating effects on the employees especially the women in managerial position and the institution.

\section{Conclusion}

The study realized that women managers experience stress as a result of the double burden of two jobs: managing a home and an institution, which many of the women agree is a taxing business. The hassle of daily domestic chores coupled with organizational errands such as training, planning, controlling and supervising breeds' pressure which heightens their stresses. The women identified recreation, self-care, social support and relational coping as some of the techniques by which they strive to cope with stresses unconsciously to prevent the negative health impact. Periodic trainings, workshops/seminars, stress management trainings and mandatory check-ups are to be instituted together with flexible work time-table to prevent the women and the state from ripping the full negative effects from stress and related cost. Stress is a personalized phenomenon and therefore the principle of individual differences must be considered in the design and selection of management strategies to mitigate its effects. The marital and dependant statistics of the study contradict the belief or misconception in the Ghanaian society that women who attain high educational status or high professional status in society are generally unable to submit to their male counterpart especially in marriage and are thus divorcees or single parents; and they tend not to have too many children or dependants.

Some limitations to this research have been identified both from literature review and empirical study perspectives. Empirically, a larger sample size, selected more randomly from both private and government organisations would have provided a sturdier research design which would allow the result to be more applicable or generalizable rather than sampling few women as in the present study. The OSI-R has not been validated on Ghanaian populations or sample and as such cultural differences could have influenced the responses to the questions, especially where respondents were from a different sub-cultural background. Supplementary information like performance rating, absenteeism records, health questionnaires and medical records could have provided other objective measures, not simply relying on self-report results. There was no evaluation of organisational climate and culture or management style which could 
have provided useful insight into the background in which the women fulfil their work roles and interactions.

\section{Recommendations}

Stress is global pandemic which requires an all-inclusive stress coping mechanism that includes interventions by the institutions, counsellors, society, family members and the women managers to moderate the impacts of stress in their lives and reduce the cost associated with absenteeism, hospital bills and psychological illness. Institutions should formulate flexible work schedule, family-friendly policies and build crèches to mitigate the stress and health complications that these women experience. Periodic seminars/workshops and counselling sessions on stress management should be organized by institutions while encouraging their staff to take their annual leave, undergo mandatory annual medical check-up to promote their wellbeing and undergo counselling sessions to enhance the women's health and afford them opportunity to acquire stress management skills which they can also share with their colleagues. Conducive working environment should be created to enable them to bring their unique characteristic including multi-task, team spirit, participatory leadership and use of diverse styles to inspire their subordinates to work hard to increase productivity and achieve set goals. Additionally, it is important for the organisation to know that both the individual and organisational level interventions are necessary to ensure effective stress management.

\section{Conflicts of Interest}

The authors declare no conflicts of interest regarding the publication of this paper.

\section{References}

Abarry, N. (1997). African Cultural Values: An Introduction. Journal of Black Studies, 27, 419-421. https://doi.org/10.1177/002193479702700309

Adasi, G. S., Amponsah, K. D., Mohammed, S. M., Yeboah, R., \& Mintah, P. C. (2020). Gender Differences in Stressors and Coping Strategies among Teacher Education Students at University of Ghana. Journal of Education and Learning, 9, 123-133. https://doi.org/10.5539/jel.v9n2p123

Addison, A. K., \& Yankyera, G. (2015). An Investigation into How Female Teachers Manage Stress and Teacher Burnout: A Case Study of West Akim Municipality of Ghana. Journal of Education and Practice, 6, 1-24.

Adekola, B. (2010). Interferences between Work and Family among Male and Female Executives in Nigeria. African Journal of Business Management, 4, 1069-1077.

Ajayi, S. (2018). Effect of Stress on Employee Performance and Job Satisfaction: A Case Study of Nigerian Banking Industry. https://doi.org/10.2139/ssrn.3160620

Amponsah, K. D., Adasi, G. S., Mohammed, S. M., Ampadu, E., \& Okrah, A. K. (2020). Stressors and Coping Strategies: The Case of Teacher Education Students at University of Ghana. Cogent Education, 7, Article ID: 1727666.

https://doi.org/10.1080/2331186X.2020.1727666 
Amporfu, E., Sakyi, D., Frimpong, P. B., Arthur, E., \& Novignon, J. (2018). The Distribution of Paid and Unpaid Work among Men and Women in Ghana: The National Time Transfer Accounts Approach (No. cwwwp3).

Amu, N. J. (2005). The Role of Women in Ghana's Economy. Bonn: Friedrich Ebert Foundation.

Bacchus, D. N. A. (2008). Coping with Work-Related Stress; a Study of the Use of Coping Resources among Professional Black Women. Journal of Ethnic and Cultural Diversity in Social Work, 17, 60-81. https://doi.org/10.1080/15313200801906443

Baltus, R. K. (1997). Personal Psychology for Life and Work (4th ed.). New York: McGraw Hill.

Benson, R. B., Cobbold, B., Boamah, E. O., Akuoko, C. P., \& Boateng, D. (2020). Challenges, Coping Strategies, and Social Support among Breast Cancer Patients in Ghana. Advances in Public Health, 2020, Article ID: 4817932. https://doi.org/10.1155/2020/4817932

Clark, C. M. (2013). Creating \& Sustaining Civility in Nursing Education. Indianapolis, IN: SIGMA Theta Tau International Center for Nursing.

Clarke, S. G., \& Cooper, C. L. (2000). The Risk Management of Occupational Stress. Health, Risk \& Society, 2, 173-187. https://doi.org/10.1080/713670158

Coleman, D., \& Iso-Ahola, S. E. (1993). Leisure and Health: The Role of Social Support and Self-Determination. Journal of Leisure Research, 25, 111-128. https://doi.org/10.1080/00222216.1993.11969913

Creswell, J. W. (2009). Research Design: Qualitative, Quantitative, and Mixed Approaches (3rd ed.). Thousand Oaks, CA: Sage.

Diabah, G. (2018). The Representation of Women in Ghanaian Radio Commercials: Sustaining or Challenging Gender Stereotypes? Language in Society, 48, 1-23.

Diabah, G., \& Amfo, N. A. A. (2015). To Dance or Not to Dance: Masculinities in Akan Proverbs and Their Implications for Contemporary Societies.

Donkor, E. S., \& Sandall, J. (2009). Coping Strategies of Women Seeking Infertility Treatment in Southern Ghana. African Journal of Reproductive Health, 13, 81-94.

Folke, O., \& Rickne, J. (2020). All the Single Ladies: Job Promotions and the Durability of Marriage. American Economic Journal: Applied Economics, 12, 260-287. https://doi.org/10.1257/app.20180435

Folkins, C. H., \& Sime, W. E. (1981). Physical Fitness Training and Mental Health. American Psychologist, 36, 373. https://doi.org/10.1037/0003-066X.36.4.373

Forbus, P., Newbold, J., \& Mehta, S. (2010). University Commuter Students: Time Management, Stress Factors and Coping Strategies. Advances in Business Research, 1, 142-151.

Ganle, J. K., Afriyie, K., \& Segbefia, A. Y. (2015). Microcredit: Empowerment and Disempowerment of Rural Women in Ghana. World Development, 66, 335-345. https://doi.org/10.1016/j.worlddev.2014.08.027

Glazebrook, T., Noll, S., \& Opoku, E. (2020). Gender Matters: Climate Change, Gender Bias, and Women's Farming in the Global South and North. Agriculture, 10, 267. https://doi.org/10.3390/agriculture10070267

Gonzalez, A., Ruiz, A., Serrano, R., Ariño, J., \& Casamayor, A. (2006). Transcriptional Profiling of the Protein Phosphatase 2C Family in Yeast Provides Insights into the Unique Functional Roles of Ptc1. Journal of Biological Chemistry, 281, 35057-35069. https://doi.org/10.1074/jbc.M607919200

Greenglass, E. (2002). Work Stress, Coping and Social Support: Implications for Wom- 
en's Occupational Well-Being (pp. 85-96). Washington DC: APA. https://doi.org/10.1037/10467-006

Gyekye, S. A. (2003). Causal Attributions of Ghanaian Industrial Workers for Accident Occurrence: Miners and Non-Miners' Perspective. Journal of Safety Research, 34, 533-538. https://doi.org/10.1016/j.jsr.2003.03.002

Halbesleben, J. R. B. (2010). Managing Stress and Preventing Burnout in the Workplace. Chicago, IL: Foundation of the American College of Health Foundation.

Hall, K., Gibbie, T., \& Lubman, D. I. (2012). Motivational Interviewing Techniques: Facilitating Behaviour Change in the General Practice Setting. Australian Family Physician, 41,660 .

Hegewisch, A., \& DuMonthier, A. (2016). The Gender Wage Gap: 2015: Annual Earnings Differences by Gender, Race, and Ethnicity. Institution for Women's Policy Research.

Innstrand, S. T., Espnes, G. A., \& Mykletun, R. (2004). Job Stress, Burnout and Job Satisfaction: An Intervention Study for Staff Working with People with Intellectual Disabilities. Journal of Applied Research in Intellectual Disabilities, 17, 117-119. https://doi.org/10.1111/j.1360-2322.2004.00189.x

Jones, F. I., \& Bright, J. (2001). Stress: Myth, Theory, and Research. Harlow: Prentice Hall.

Kerr, J. L. et al. (2012). Use of Recreation Activities as Positive Coping with Chronic Stress and Mental Health Outcomes Associated with Unemployment of People with Disabilities. Work, 43, 279-292. https://doi.org/10.3233/WOR-2012-1390

Kompier, M., \& Cooper, C. (1999). Introduction: Improving Work, Health and Productivity through Stress Prevention. In M. Kompier, \& C. Cooper (Eds.), Preventing Stress, Improving Productivity European Case Studies in the Workplace (pp. 1-8). London: Routledge.

Kusi, H., Codjoe, A., \& Bampo, J. (2018). Occupational Stress among Female Lecturers at the University of Education, Winneba, (Winneba Campus), Ghana and Management Strategies. International Journal of Development and Sustainability, 7, 2637-2651.

Lazarus, R. S., \& Folkman, S. (1984). Stress, Appraisal, and Coping. Berlin: Springer Publishing Company.

LeDuc, K. (2010). Baccalaureate Nursing Student' Stress and Coping Resources. Research News, $17,1-2$.

Lemay, V., Hoolahan, J., \& Buchanan, A. (2018). SAMYAMA: Stress Anxiety, and Mindfulness; A Yoga and Meditation Assessment. American Journal of Pharmaceutical Education, 83, Article 7001. https://doi.org/10.5688/ajpe7001

Maddi, S. R., \& Khoshaba, D. M. (2005). Resilience at Work: How to Succeed No Matter What Life Throws at You. New York: AMACOM.

Mbiti, J. S. (1969). African Religion and Philosophy. London: Heinemann.

McCombes, S. (2019). How to Create a Research Design. http://www.scribbr.com/research-process/research-design

Myers, S. B., Sweeney, A. C., Popick, V., Wesley, K., Bordfeld, A., \& Fingerhut, R. (2012). Self-Care Practices and Perceived Stress Levels among Psychology Graduate Students. Training and Education in Professional Psychology, 6, 55. https://doi.org/10.1037/a0026534

Nadinloyia, K. B., Sadeghib, H., \& Hajolooc, N. (2013). Relationship between Job Satisfaction.

Nkulenu, A. O. (2015). Effect of Work-Family Conflict on Quality of Work-Life in Gha- 
na. European Journal of Business and Management, 7, 52-61.

OECD (2012). Equity and Quality in Education: Supporting Disadvantaged Students and Schools. Paris: OECD Publishing. https://doi.org/10.1787/9789264130852-en.

Ofei, A. M. A., Kwashie, A. A., Asiedua, E., Serwaa, N., \& Akotiah, A. N. (2018). Stress and Coping Strategies among Nurse Managers at Three District Hospitals in the Eastern Region of Ghana. NUMID HORIZON: An International Journal of Nursing and Midwifery, 2, 1-13.

Okeke, N. L., Davy, T., Eron, J. J., \& Napravnik, S. (2016). Hypertension among HIV-Infected Patients in Clinical Care, 1996-2013. Clinical Infectious Diseases, 63, 242-248. https://doi.org/10.1093/cid/ciw223

Osipow, S. H. (1998). Occupational Stress Inventory-Revised Edition (OSI-R). Odessa, FL: Psychological Assessment Resources, Inc.

Osipow, S. H., \& Davis, A. (1988). The Relationship of Coping Resources to Occupational Stress and Strain. Journal of Vocational Behaviour, 32, 1-15. https://doi.org/10.1016/0001-8791(88)90002-4

Osipow, S. H., \& Spokane, A. R. (1984). Measuring Occupational Stress, Strain, and Coping. In S. Oskamp (Ed.), Applied Social Psychology Annual 5: Applications in Organizational Settings (pp. 67-86). Beverly Hills, CA: Sage.

Oti-Boadi, M., \& Asante, K. O. (2017). Psychological Health and Religious Coping of Ghanaian Women with Infertility. BioPsychoSocial Medicine, 11, 1-7.

https://doi.org/10.1186/s13030-017-0105-9

Owusu, G. A., \& Tawiah, M. A. (2014). Stress Management among Senior Staff Female Administrators in the University of Cape Coast. International Journal of Academic Research in Progressive Education and Development, 3, 78-100. https://doi.org/10.6007/IJARPED/v3-i4/1143

Pargament, K. I., Smith, B. W., Koenig, H. G., \& Perez, L. (1998). The Patterns Positive and Negative Religious Coping with Major Life Stressors. Journal for the Scientific Study of Religion, 37, 710-724. https://doi.org/10.2307/1388152

Park, S. H., \& Kim, Y. (2018). Ways of Coping with Excessive Academic Stress among Korean Adolescents during Leisure Time. International Journal of Qualitative Studies on Health and Well-Being, 13, Article ID: 1505397. https://doi.org/10.1080/17482631.2018.1505397

Picciano, A. G. (2004). Educational Research Primer. London, New York: Continuum.

Pines, A., \& Aronson, E. (1988). Career Burnout: Causes and Cures. New York: Free Press Publishing.

Punch, F. K. (2005). Introduction to Social Research: Quantitative and Qualitative Approaches. London: Sage Publication.

Riley, K. E., \& Park, C. L. (2015). How Does Yoga Reduce Stress? A Systematic Review of Mechanisms of Change and Guide to Future Inquiry. Health Psychology Review, 9, 379-396. https://doi.org/10.1080/17437199.2014.981778

Robbins, S. P., \& Sanghi, S. (2006). Organizational Behaviour (11th ed.). Delhi: Dorling Kindersley (India) Pvt.

Roberts, C. (2014). Stress Coping Strategies among Ghanaian Women in Managerial Positions. European Scientific Journal, 10.

Rotter, J. B. (1966). Generalized Expectancies for Internal versus External Control of Reinforcement. Psychological Monographs, 80, 1-28. https://doi.org/10.1037/h0092976

Roudsari, R. L., \& Allan, H. T. (2011). Women's Experiences and Preferences in Relation to Infertility Counselling: A Multifaith Dialogue. International Journal of Fertility \& 
Sterility, 5, 158.

Ryan, M. A. (1998). Faith and Infertility. In M. T. Lysaugh, J. Kotva, S. E. Lammer, \& A. Verhey (Eds.), On Moral Medicine: Theological Perspectives on Medical Ethics (pp. 865-869). Cambridge: WB Eerdmans.

Sackey, J., \& Sanda, M. (2011). Sustenance of Human Capital: Social Support as a Managerial Stress Reliever for Women in Developing Economies. Research and Practice in Human Resource Management, 19, 1-23.

Sackey, J., \& Sanda, M. A. (2009). Influence of Occupational Stress on the Mental Health of Ghanaian Professional Women. International Journal of Ergonomics, 39, 876-887. https://doi.org/10.1016/j.ergon.2009.04.003

Saunders, M., Lewis, P., \& Thornhill, A. (2009). Research Methods for Business Students. New York: Pearson.

Saunders, M., Lewis, P., \& Thornhill, A. (2012). Research Methods for Business Students (6th ed.). New York: Pearson Educational Limited.

Selye, H. (1976). Stress in Health and Disease. Boston, MA: Butterworth's Inc.

Semmer, N., Zapf, D., \& Greif, S. (1996). "Shared Job Strain": A New Approach for Assessing the Validity of Job Stress Measurements. Journal of Occupational and Organizational Psychology, 69, 293-310. https://doi.org/10.1111/j.2044-8325.1996.tb00616.x

Stamarski, C. S., \& Son Hing, L. S. (2015). Gender Inequalities in the Workplace: The Effects of Organizational Structures, Processes, Practices, and Decision Makers' Sexism. Frontiers in Psychology, 6, Article 1400. https://doi.org/10.3389/fpsyg.2015.01400

Thurston, R. C., Sherwood, A., Matthews, K. A., \& Blumenthal, J. A. (2011). Household Responsibilities, Income, and Ambulatory Blood Pressure among Working Men and Women. Psychosomatic Medicine, 73, 200-205. https://doi.org/10.1097/PSY.0b013e3182080e1a

Trivellasa, P., Reklitisa, P., \& Latis, C. (2013). The Effects of Job-Related Stress on Employee' Satisfaction: A Survey in Health Care. Procedia and Behavioural Sciences, 73, 718-726. https://doi.org/10.1016/j.sbspro.2013.02.110

Twumasi, P. A. (1975). Medical Systems in Ghana: A Study in Medical Sociology (Vol. 4, pp. 413-433). Accra: Ghana Publishing Corporation.

WHO World Health Organization (2018). 2018 Global Reference List of 100 Core Health Indicators (plus Health-Related SDGs) (No. WHO/HIS/IER/GPM/2018.1).

Willis, R. J. B. (2005). Cracking the Stress Problem. Grantham: The Stanborough Press Ltd.

Wireko-Gyebi, S., Adu-Frimpong, G. K., \& Ametepeh, R. S. (2017). Work-Related Stress: Coping Strategies of Frontline Hotel Employees in Ghana. Anatolia, 28, 197-208. https://doi.org/10.1080/13032917.2017.1289965

Yearbook, F. S. (2013). World Food and Agriculture (p. 15). Rome: Food and Agriculture Organization of the United Nations.

Yin, R. K. (2011). Qualitative Research from Start to Finish. New York: A Division of Guilford Publication. 